\title{
Variable PSII functioning and bleaching conditions of tropical scleractinian corals pre-and post-bleaching event
}

\author{
SUSHMA MATTAN-MOORGAWA ${ }^{1,3, \bullet}$, SOONIL DDV RUGHOOPUTH ${ }^{2}$, RANJEET BHAGOOLI ${ }^{1,3,4, \bullet}$ \\ ${ }^{1}$ Department of Biosciences and Ocean Studies, Faculty of Science, University of Mauritius. Réduit 80837, Republic of Mauritius. Tel.: +230-4037916, \\ Fax.: +230-4656928, `email: s.moorgawa@uom.ac.mu, vr.bhagooli@uom.ac.mu \\ ${ }^{2}$ Department of Physics, Faculty of Science, University of Mauritius. Réduit 80837, Republic of Mauritius \\ ${ }^{3}$ The Biodiversity and Environment Institute, Réduit. Republic of Mauritius \\ ${ }^{4}$ Institute of Oceanography and Environment (INOS), Universiti Malaysia Terengganu. 21030 Kuala Terengganu, Terengganu, Malaysia
}

Manuscript received: 1 May 2018. Revision accepted: 8 June 2018.

\begin{abstract}
Mattan-Moorgawa S, Rughooputh SDDV, Bhagooli R. 2018. Variable PSII functioning and bleaching conditions of tropical scleractinian corals pre-and post-bleaching event. Ocean Life 1: 1-10. This study compared pre-bleaching and post-bleaching conditions of eight reef-building corals, Acropora cytherea, Acropora hyacynthus, Acropora muricata, Acropora sp., Pocillopora damicornis, Pocillopora eydouxi, Galaxea fascicularis and Fungia sp., in terms of visual coloration (non-bleached (NB), pale (P), partially bleached (PB) and bleached (B)) and chlorophyll fluorescence yield at photosystem II (PSII)). A total of twenty colonies from twelve stations along four transects were surveyed at Belle-Mare, Mauritius, from October 2008 to October 2009, and compared to the CoralWatch Coral Health Chart. PSII functioning, measured as Fv/Fm, were recorded in coral samples using a pulse-amplitudemodulated (PAM) fluorometer. Physico-chemical parameters (sea surface temperature, dissolved oxygen, salinity and $\mathrm{pH}$ ) were recorded in situ. An increase in SST up to $31.4^{\circ} \mathrm{C}$ in February 2009 triggered the bleaching event observed in May 2009 at the site. Acroporids showed the first sign of bleaching and paling as from January 2009 when mean SST was at $30^{\circ} \mathrm{C}$. Branching coral $(P$. eydouxi) and solitary coral (Fungia sp.) exhibited only 15\% of their colonies showing paling by April 2009. A. cytherea, A. hyacynthus, and A. muricata showed varying bleaching conditions [Pale (P), Partially-bleached (PB) and Bleached (B)] at onset of the bleaching event whilst Acropora sp. showed only a paling of its colonies. Post-bleaching data indicated a differential recovery in visual coloration and PSII functioning among the corals. P. eydouxi and Fungia sp. showed no bleaching conditions throughout the study. P. damicornis and G. fascicularis indicated a quick coloration recovery from $\mathrm{P}$ to NB after the bleaching event, although their maximum quantum yield at PSII did not show significant changes in P and NB samples. A. muricata recovered faster than A. hyacynthus and A. cytherea in terms of PSII functioning. A differential recovery was observed post-bleaching event among the eight coral species, in terms of recovery of color and PSII functioning. The order of recovery was as follows: massive-like/ solitary corals > branching and semi-bulbous corals > tabular corals.
\end{abstract}

Keywords: Bleaching, climate change, PSII functioning, reef-building corals, PAM

\section{INTRODUCTION}

Coral bleaching occurs as a stress response in reefbuilding corals exposed to acute short-term stress or to long-term exposure to environmental stress, from both natural and anthropogenic sources. Muscatine et al. (1981) reported that in the symbiotic relationship between coral host and its symbiont, the host can obtain up to $100 \%$ of its daily carbon requirements from photosynthesis in its endosymbiont. The coral bleaching process takes place due to breakdown of the photosynthetic machinery (Photosystem II or PSII) of Chlorophyll $a$ (Chl $a$ ) of the endosymbiotic dinoflagellate (Genus Symbiodinium). Breakdown of PSII and subsequent degradation can lead to loss of pigments and/or loss of zooxanthellae, leading to subsequent paling or whitening of corals. The cellular processes and/or mechanisms for the expulsion of zooxanthellae during bleaching are still unclear (Baker et al. 2008).

The extent of damage at the level of PSII in zooxanthellae symbionts has been attributed to: (i) interactions between temperature and light (Iglesias-Prieto. 1997; Fitt and Warner 1995; Lesser et al. 1996; Warner et al. 1996; Jones et al. 1998; Brown et al. 2000; Fitt et al. 2001; Bhagooli and Hidaka 2006); (ii) production of reactive oxygen species (ROS) (Baird et al. 2009); lipid composition of the symbiont thylakoid membranes that affects its structural integrity at higher temperatures (Tchernov et al. 2004); and increased levels of nitric acid synthase (Trapido-Rosenthal et al. 2005).

Intra-specific and intra-specific differential responses of scleractinian corals have been reported in a number of studies (Loya et al. 2001; Brown et al. 2002; Bhagooli and Hidaka 2003; Visram and Douglas 2007; Sampayo et al. 2008; Louis et al. 2016) and have been attributed to both dinoflagellate symbiont and animal host. In symbionts, physiologically distinct lines (or clades) of Symbiodinium spp. may confer differential thermal thresholds on coral host. The coral host may also contribute to the differential response (Baird et al. 2009; Bhagooli et al. 2008; Baird et al. 2010) in the coral by adopting different ways to reduce UV and light flux to its symbionts, such as production of 
fluorescent pigments, mycosporine-like amino acids, antioxidant systems and stress enzymes.

Few ex-situ (Hoegh-Guldberg and Jones 1999; Warner et al. 1999; Grottoli et al. 2006) and in-situ studies (Warner et al. 1999; Bhagooli and Hidaka 2003, 2004; Yakovleva and Hidaka 2004) have reported the mechanisms of recovery from bleaching in scleractinian corals. Jones and Yellowlees (1997) reported that algal densities in corals remain remarkably constant as a result of carefully regulated control mechanisms such as: pre-mitotic control of zooxanthellae; growth inhibitory factors or limitation of algal nutrient supply; post-mitotic control by digestion of healthy or senescent zooxanthellae; or expulsion of excess or senescent zooxanthellae. Bleached corals recover their algal population by division of remaining zooxanthellae (Jones and Yellowlees 1997) or shifts in symbiont communities to opportunistic and resilient members of Clade D (Thornhill et al. 2006; LaJeunesse et al. 2009) or by symbiotic flexibility which provide corals with a mechanism to respond to environmental change (Sylverstein et al. 2012). Space limitation, that is space availability and symbiont size, determines algal densities in corals and the constancy of algal density between species, growth forms, and over depth and geographic range.

Rodrigues et al. (2008) studied the changes in chlorophyll fluorescence over long term bleaching and recovery in two Hawaiian coral species, Porites compressa and Montipora capitata, under controlled ex-situ conditions. The study reported that zooxanthellae of $P$. compressa were more resilient to bleaching and exhibited faster recovery due to the following factors: host feeding strategies during recovery from bleaching; zooxanthellae clade type (Type $\mathrm{C} 15$ in $P$. compressa); and $\mathrm{Chl} a$ recovery by zooxanthellae symbionts.

Van Woesik et al. (2011) revisited the winners and losers of coral bleaching over a 14 -year period. The authors concluded that short-term winners were the thermallytolerant encrusting and massive coral morphologies (Porites and faviids) and Acropora colonies (smaller than $<5 \mathrm{~cm}$ in diameter). Long-term winners were revealed as (i) thermally tolerant, locally persistent colonies, (ii) remnant survivors that rapidly regrew, and (iii) regionally persistent colonies that recruited. McCowan et al. (2012) hypothesized that in species with polyps that are physiologically independent, (e.g. massive colonies) only polyps directly affected by both heat and light respond as predicted by the photoinhibition model of coral bleaching of Jones et al. (1998). As a result, bleaching within the colony is patchy and rates of whole colony mortality are low, which is a typical response of most massive species. Moreover, taxa that are highly integrated cannot contain the damage and rates of whole colony mortality are therefore high (e.g. Acropora) (McCowan et al. 2012).

The present study was carried out to investigate recovery of eight species of reef-building corals of Mauritius following a major single bleaching event recorded in May 2009 at the lagoon of Belle Mare, Mauritius (Mattan-Moorgawa et al. 2012). The study aimed the following: (i) to investigate the bleaching susceptibilities prior to and the recovery post May 2009 bleaching event; (ii) to assess recovery of coloration in bleached, partially-bleached, pale and non-bleached colonies of eight test coral species; (iii) to investigate recovery of photosynthetic functioning of zooxanthellae in same coral colonies in terms of maximum quantum yield, Fv/Fm, at photosystem II (PSII) using a Pulse-AmplitudeModulated fluorometer, and; (iv) to investigate the effect of physical parameters on bleaching and recovery patterns of the coral colonies.

\section{MATERIALS AND METHODS}

\section{Field work}

Four transects of approximately $800 \mathrm{~m}$ running from coast to reef were surveyed in the lagoon of Belle Mare, each comprising 3 stations at near-shore, mid-lagoon and back-reef habitats. A total of 12 stations with 20 colonies of eight reef-building coral species were surveyed for an assessment of bleaching and subsequent recovery over time. The twenty coral colonies were first tagged in October 2008 for monitoring of bleaching. After the single bleaching event recorded in May 2009, the colonies exhibiting different bleaching conditions [non-bleached (NB), pale (P), partially bleached (PB) and bleached (B)] were re-tagged for follow up on the recovery from May to October 2009. Coral colonies were tagged with fluorescent tapes for easy identification during the span of the study, and the tapes were removed after completion of study.

\section{Sample collection and preparation}

Colonies of eight reef-building corals, Acropora cytherea, Acropora hyacynthus, Acropora muricata, Acropora sp., Pocillopora damicornis, Pocillopora eydouxi, Galaxea fascicularis and Fungia sp., of varying conditions (partially bleached (PB), pale (P), bleached (B) and non-bleached (NB) were collected from twenty tagged colonies at twelve stations at the study site. Non-bleached (NB) condition indicates that whole colony looks healthy and normal colour; Pale $(\mathrm{P})$ condition indicates overall paling of colony; Partially-bleached (PB) condition indicates colony which exhibits less that $30 \%$ bleaching/ whitening; Bleached (B) condition indicates colony which exhibits $>90 \%$ bleaching/ whitening. Coral tips of $2-3 \mathrm{~cm}$ were collected and kept in seawater in $250 \mathrm{ml}$ sampling bottles. Coral samples were brought to laboratory and darkadapted to allow the photosynthetic endosymbionts to relax all their PSII reaction centres before measurement of maximum quantum yield, $F_{\mathrm{v}} / \mathrm{F}_{\mathrm{m}}$.

\section{Chlorophyll a fluorescence measurements}

Chlorophyll fluorescence was measured using a teaching PAM fluorometer. Initial fluorescence (Fo) was measured by applying pulses of weak red light $(<1 \mu \mathrm{mol}$ quanta $\left.\mathrm{m}^{-2} \mathrm{~s}^{-1}\right)$ and a saturating pulse $\left(3000 \mu \mathrm{mol}\right.$ quanta $\mathrm{m}^{-}$ ${ }^{2} \mathrm{~s}^{-1}, 0.8 \mathrm{~s}$ duration) was applied to determine maximal fluorescence $\left(\mathrm{F}_{\mathrm{m}}\right)$ when all PSII centres were closed. Ratio of change in fluorescence $\left(\mathrm{F}_{\mathrm{v}} / \mathrm{F}_{\mathrm{m}}\right)$ caused by the saturating pulse to the maximal fluorescence $\left(\mathrm{F}_{\mathrm{m}}\right)$ in a dark-adapted sample, is correlated to the maximum quantum yield of 
PSII and thus represent the PSII functioning (Genty et al. 1989).

\section{In-situ measurements of physical parameters}

Temperature (OAKTON $\mathrm{pH} / \mathrm{mv} /{ }^{\circ} \mathrm{C}$ meter $\mathrm{pH} 300$ series) and other physical parameters, namely dissolved oxygen (Hach Sension 6), salinity and $\mathrm{pH}$ (OAKTON waterproof $\mathrm{pH} 300$ series) were measured in situ and recorded on a monthly basis from May 2009 to October 2009.

\section{Statistical analysis}

Mean values and standard deviations were calculated for the maximum quantum yield for the four different conditions (PB, P, B and NB) in the eight species of coral.

\section{RESULTS AND DISCUSSION}

\section{Physical parameters}

Recorded physical parameters from October 2008 to October 2009 included average temperature, dissolved oxygen, salinity and $\mathrm{pH}$ values (Figure 1). Mean salinity varied over the study period with highest mean salinity recorded in August 2009 at $35.25 \%$ and lowest at $33.25 \%$ recorded in April 2009. Mean dissolved oxygen fluctuated over the study period with lowest levels $\left(7 \mathrm{mgL}^{-1}\right)$ recorded in October 2009 and peak levels $\left(20.38 \mathrm{mgL}^{-1}\right)$ in May 2009. Mean $\mathrm{pH}$ levels varied slightly over the study period at an average of 7 with an abnormally lower $\mathrm{pH}$ recorded at 8.45 in August 2009. Mean seawater temperature at sampling stations indicated a seasonal trend with mean lowest temperatures recorded at $23.9^{\circ} \mathrm{C}$ in winter month of September 2009 and mean highest temperatures recorded at $31.4^{\circ} \mathrm{C}$ in February 2009. There was a gradual increase in sea surface temperatures from October $2008\left(26.6^{\circ} \mathrm{C}\right)$ to February $2009\left(31.4^{\circ} \mathrm{C}\right)$ after which it decreased gradually to $27.5^{\circ} \mathrm{C}$ in May 2009. Lowest mean sea surface temperatures were recorded in October 2009 at $24.1^{\circ} \mathrm{C}$

\section{Percentage bleaching occurrence in sampled colonies pre-bleaching event}

All surveyed coral colonies appeared non-bleached and healthy over the first three summer months from October 2008 to December 2008. In January 2009, the first cases of paling (P) and bleaching (B) were recorded in A. muricata (15\%) and Acropora sp. (25\%), and in A. cytherea (15\%) and $A$. hyacynthus (20\%) (Figure 2).

All $(100 \%)$ colonies of Fungia sp. and P. eydouxi were non-bleached (NB) throughout the study period. Surveyed colonies of $P$. damicornis and $G$. fascicularis showed 100\% NB condition from October 2008 until March 2009. In April 2009, both $P$. damicornis and $G$. fascicularis showed paling $(\mathrm{P})$ for $15 \%$ of the colonies, and in May 2009 , percentage of colonies showing paling increased up to $25 \%$ in $P$. damicornis and up to $30 \%$ in $G$. fascicularis.

A. cytherea colonies showed an increasing occurrence of bleached (B) conditions from January 2009 (0\%) to May 2009 (60\%). In February 2009, A. cytherea showed all four visual conditions at $35 \% \mathrm{NB}, 35 \% \mathrm{P}, 15 \% \mathrm{~PB}$ and $15 \% \mathrm{~B}$, while in May 2009 it was 25\% NB, 15\% PB and 60\% B in May 2009 (Figure 2).

A. hyacynthus colonies also showed an increasing occurrence of bleached (B) conditions from January 2009 (0\%) to May 2009 (65\%). In February 2009, A. hyacynthus showed all bleaching conditions at $60 \% \mathrm{NB}, 15 \% \mathrm{P}$ and $25 \% \mathrm{~B}$; at $45 \% \mathrm{NB}, 15 \% \mathrm{~PB}$ and $40 \% \mathrm{~B}$ in March 2009; at $40 \% \mathrm{NB}, 15 \% \mathrm{~PB}$ and $45 \% \mathrm{~B}$ in April 2009; and at 20\%NB, $15 \%$ NB and 65\% B in May 2009 (Figure 2).

A. muricata colonies also showed an increasing occurrence of bleached (B) conditions from January 2009 (0\%) to May 2009 (35\%). In February 2009, A. muricata showed all four visual conditions at $25 \% \mathrm{NB}, 50 \% \mathrm{P}$ and $25 \% \mathrm{~PB}$, as compared to $25 \% \mathrm{NB}, 15 \% \mathrm{P}, 25 \% \mathrm{~PB}$ and $35 \% \mathrm{~B}$ in May 2009 (Figure 2).

Acropora sp. colonies, on the contrary, showed the occurrence of only two conditions, NB and P, from January 2009 to May 2009, with no record of PB and P conditions. Here, the occurrence of $\mathrm{P}$ conditions increased from $25 \%$ in January 2009 to 50\% in May 2009 (Figure 2).

\section{Post-bleaching conditions of corals/ recovery}

The bleaching state / recovery conditions were investigated in surveyed coral colonies post-bleaching event in May 2009 until October 2009. Figure 3 shows a comparison of the bleaching condition in the eight studied species. Results indicated that all NB coral colonies of the eight species remained as non-bleached $(\mathrm{NB}=1)$ and in a healthy state up to October 2009.

All pale (P) colonies recorded in May 2009 in the four species, namely A. hyacynthus, A. muricata, Acropora sp., $P$. damicornis, and $G$. fascicularis recovered to the NB condition in June 2009 continuing this trend until October 2009 , to the exception of $\mathrm{P}$ colonies of $A$. cytherea which remained in the same condition $(\mathrm{P}=2)$ for May-June 2009 and only recovered $(\mathrm{NB}=1)$ as from July 2009.

Moreover, all partially bleached $(\mathrm{PB}=3)$ colonies recorded in May 2009 for A. muricata recovered to nonbleached condition ( $\mathrm{NB}=1$ ) as from June 2009 onwards indicating a rapid recovery. However, results also indicate that partially bleached (PB) colonies recorded for $A$. cytherea in May 2009 took some time to recover, attaining recovery $(\mathrm{NB}=1)$ only in August 2009.

All bleached (B) colonies recorded in May 2009 for $A$. cytherea, A. hyacynthus and A. muricata showed no improvement in June 2009 in its bleaching condition, to the exception of $A$. muricata which indicated a quick recovery from bleached $(\mathrm{B}=4)$ to pale condition $(\mathrm{P}=2)$ from May 2009 to June 2009, respectively. All B colonies of $A$. muricata gained complete recovery in July 2009. Bleached colonies recorded for A. cytherea and A. hyacynthus during the May 2009 bleaching event showed an initial recovery to PB condition only after a lapse of two months, i.e. in July 2009. Complete recovery in these two species to nonbleached $(\mathrm{NB}=1)$ condition occurred in August 2009.

\section{Chlorophyll fluorescence ratio, Fv/Fm}

Figure 4 indicated chlorophyll fluorescence ratio of in hospite zooxanthellae cells from coral samples collected from tagged coral colonies showing different visual 
conditions, namely non-bleached (NB), pale (P), partiallybleached (PB) and bleached (B). This was carried out over 6 months following the May 2009 bleaching event.

Results indicated that PSII functioning, Fv/Fm, was normal at an average of 0.6 in all NB colonies in the eight studied corals. For all tagged pale $(\mathrm{P})$ colonies, recorded Fv/Fm values were as high as 0.6 in $P$. damicornis and $G$. fascicularis, and as low as 0.4 in pale (P) colonies of $A$. hyacynthus, A. muricata and Acropora sp. over the postbleaching months from May 2009 to October 2009. Pale colonies of $P$. damicornis and $G$. fascicularis showed no significant change in PSII functioning over the post bleaching months (May 2009 to October 2009). However, P colonies of A. hyacynthus, A. muricata and Acropora sp. showed an overall recovery of PSII functioning from May $2009(\mathrm{Fv} / \mathrm{Fm}=0.4)$ to June $2009(\mathrm{Fv} / \mathrm{Fm}=0.6)$, July 2009 $(\mathrm{Fv} / \mathrm{Fm}<0.6)$ and August $2009(\mathrm{Fv} / \mathrm{Fm}=0.6)$. This indicated a slow recovery from late summer 2009 (May) to early summer 2009 (October). However, among the three Acroporids, A. muricata showed a faster recovery of its PSII functioning as compared to A. hyacynthus and Acropora sp.

For all tagged partially-bleached (PB) colonies for $A$. cytherea and $A$. muricata, recorded $\mathrm{Fv} / \mathrm{Fm}$ values were as high as 0.6 and as low as 0.45 during post-bleaching months May 2009 to October 2009. In fact, in May 2009 bleaching month, PSII functioning was lower in $A$. cytherea $(\mathrm{Fv} / \mathrm{Fm}=0.45)$ and higher in $A$. muricata $(\mathrm{Fv} / \mathrm{Fm}$ $=0.56)$. Observations made over June 2009 to October
2009 indicated a faster recovery of PSII functioning in $A$. muricata from 0.56 in May 2009 to 0.6 in early June 2009, whereas PSII functioning indicated slower recovery in $A$. cytherea from 0.45 in May 2009 to 0.6 in October 2009. In May 2009, only three species of corals exhibited the bleached (B) condition, namely A. cytherea, A. hyacynthus, A. muricata. PSII functioning recorded during May 2009 in bleached (B) colonies were as low as 0.14 in A. cytherea and A. hyacynthus, and 0.19 recorded in A. muricata. A gradual recovery of PSII functioning was observed in all three species post bleaching in May $2009(\mathrm{Fv} / \mathrm{Fm}=0.14$ $0.19)$ to October $2009(\mathrm{Fv} / \mathrm{Fm}=0.6)$. However, results indicated that $A$. muricata recovered fastest in the month of July 2009 with highest chlorophyll $a$ fluorescence ratio of 0.57 as compared to the other two Acroporids.

\section{Discussion}

This study indicated a differential recovery among eight reef-building corals, in terms of recovery of colour and recovery of PSII post-May 2009 bleaching event.

\section{Physical parameters}

It is observed that an increase of sea surface temperatures up to a maximum of $31.4^{\circ} \mathrm{C}$ in February 2009 has triggered the bleaching event in May 2009. Other physical parameters such as DO, salinity and $\mathrm{pH}$ had insignificant variations over the study period and did not affect the bleaching and/or recovery in the studied corals.
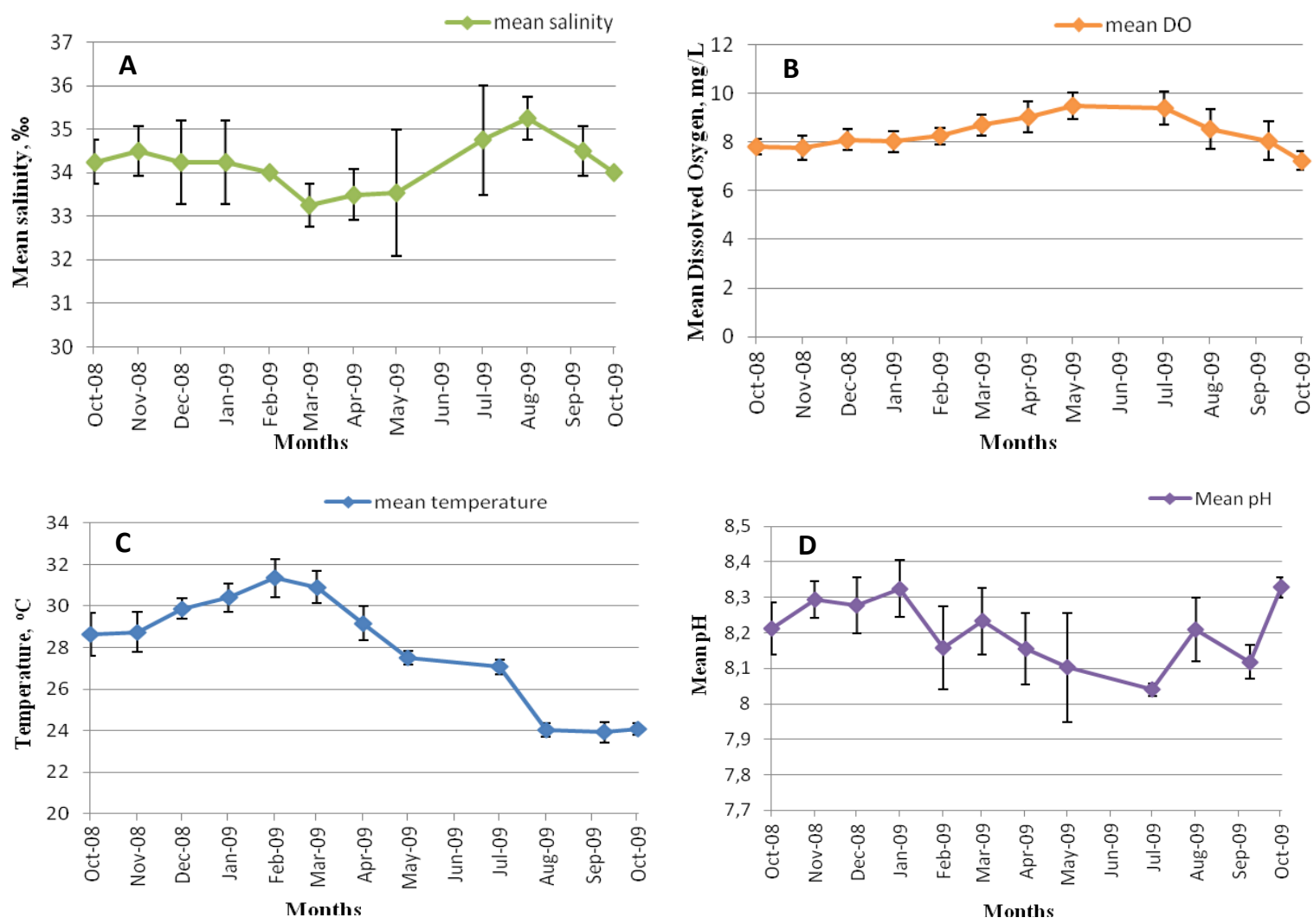

Figure 1. Physical parameters measured in situ during Oct 2008-Oct 2009: A. salinity (ppt); B. dissolved oxygen (mgL-1); C: seawater temperature $\left({ }^{\circ} \mathrm{C}\right) ; \mathrm{D}$. $\mathrm{pH}$. Data represent mean $\pm \mathrm{SD}(\mathrm{n}=12$ for each month) 

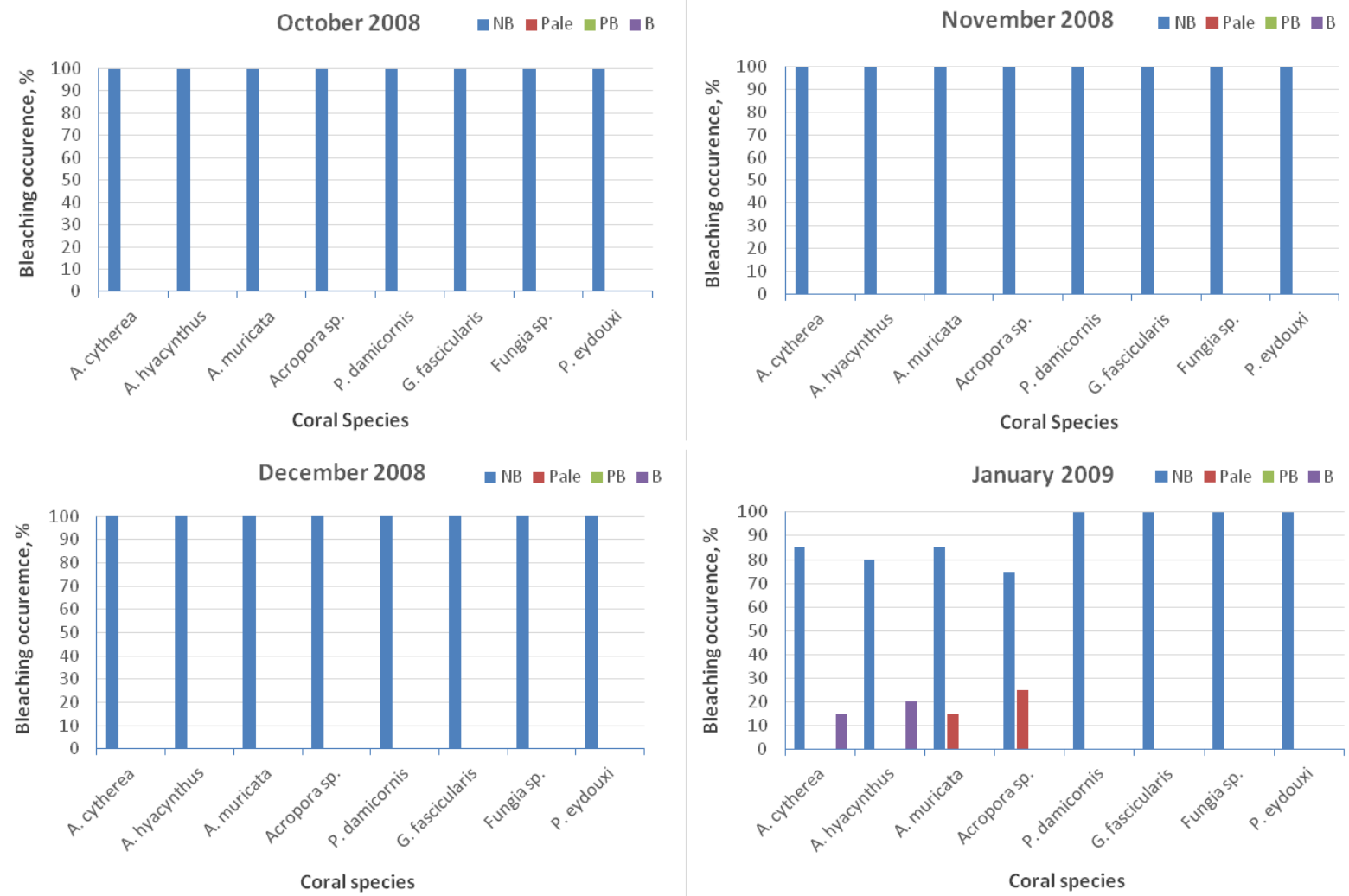

Figure 2A. Percentage bleaching occurrence (\% out of 20 colonies) in the eight studied coral species over one-year study from October 2008 to January 2009
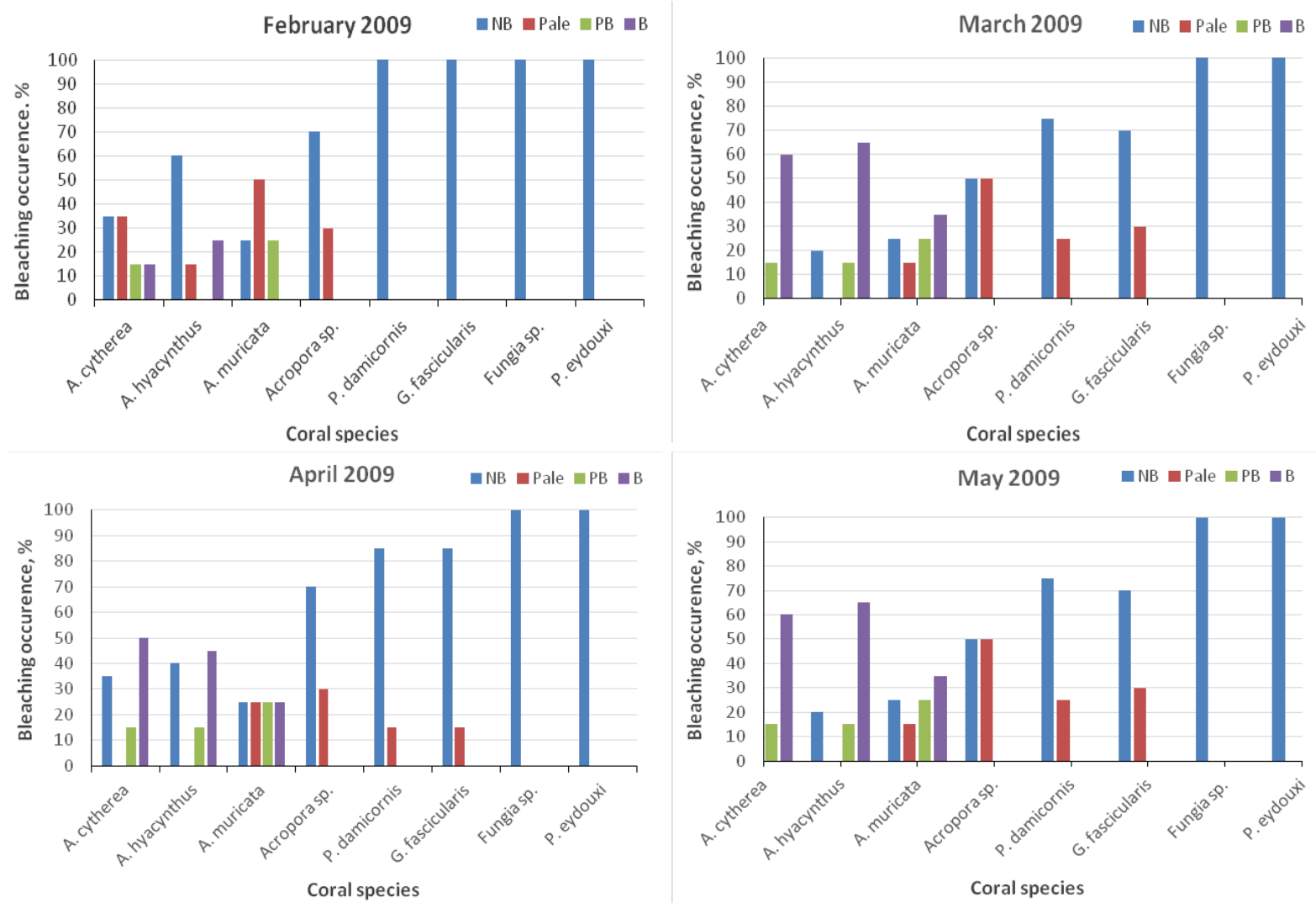

Figure 2B. Percentage bleaching occurrence (\% out of 20 colonies) in the eight studied coral species over one-year study from February 2009 to May 2009 


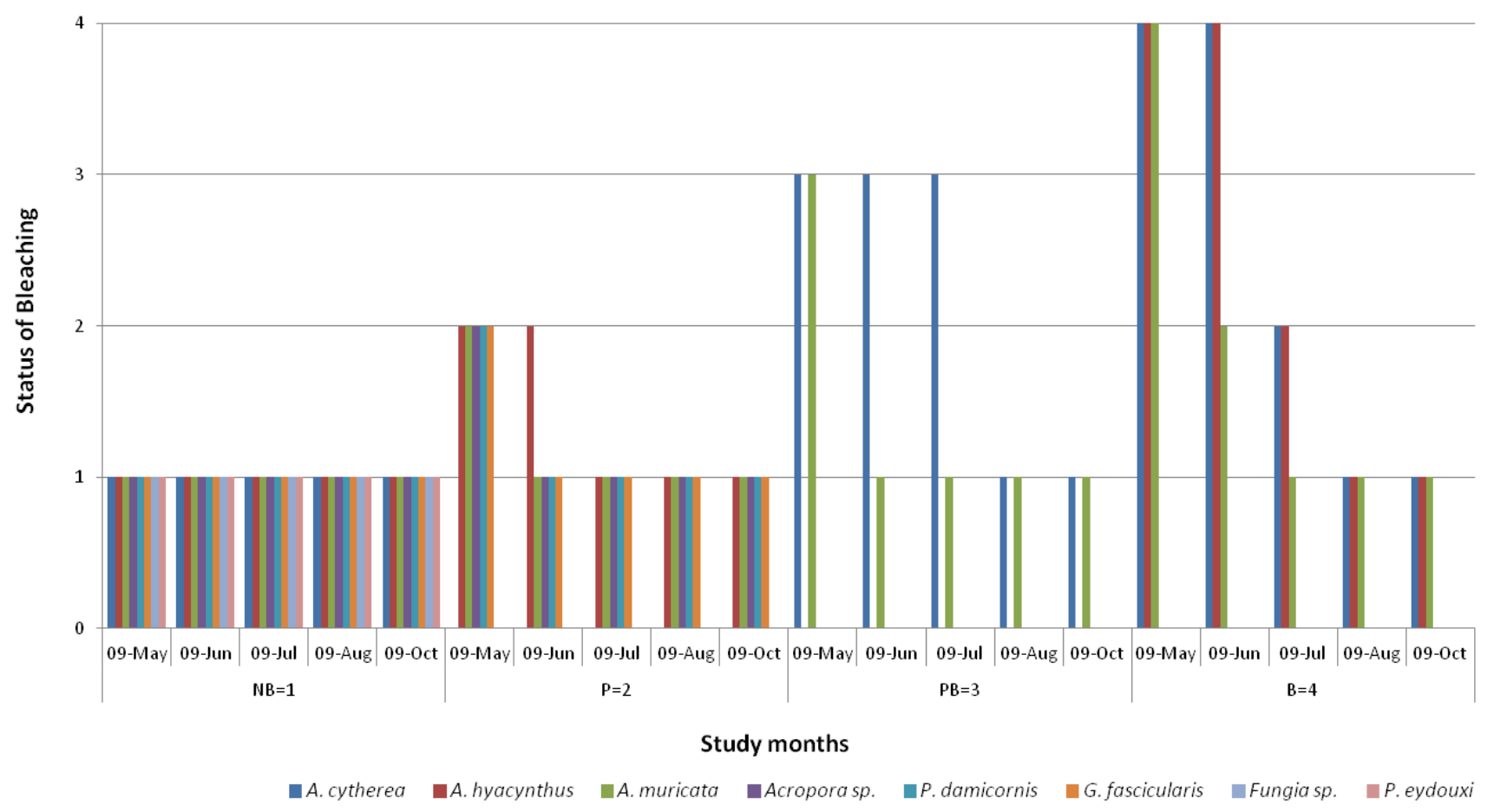

Figure 3. Percentage bleaching occurrence (\% out of 20 colonies) in the eight studied coral species over one-year study period October 2008 to May 2009
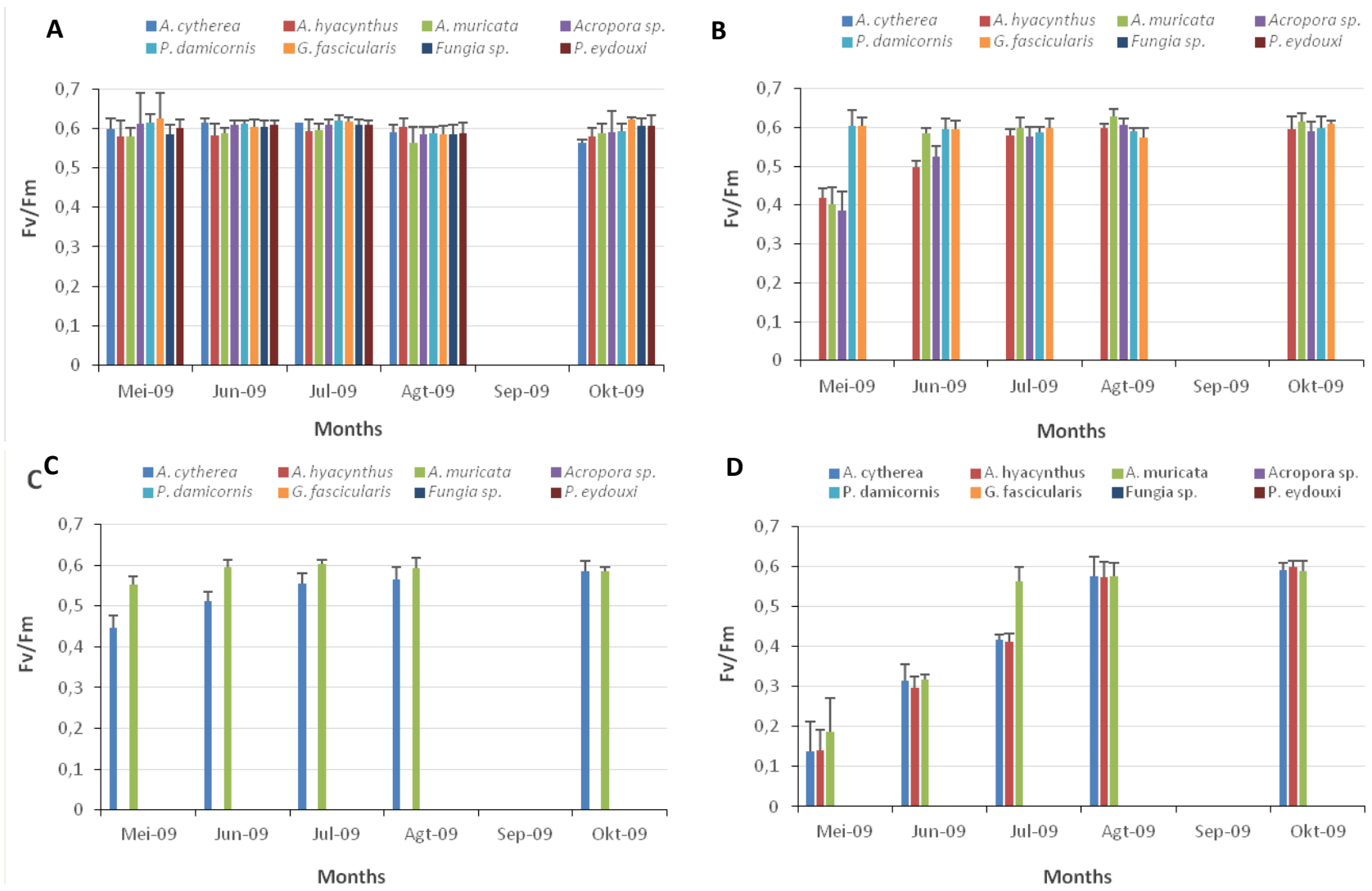

Figure 4. Post-bleaching recovery and PSII functioning $(\mathrm{Fv} / \mathrm{Fm})$ among the four different conditions of the surveyed eight coral species: A. non-bleached (NB); B. pale (P); C. partially-bleached (PB); C. bleached (B) 
Percentage bleaching occurrence in sampled coral species pre-bleaching event

Paling and bleaching signs were observed in the Acroporids as from January 2009 when mean sea surface temperatures rose above $30{ }^{\circ} \mathrm{C}$, which may have been an onset of the bleaching event down the line in May 2009. This result also suggests a pre-disposition or susceptibility of the Acroporids to elevated sea surface temperatures.). Past studies have highlighted the importance of coral growth and morphology as a contributory factor in the susceptibility and mortality of scleractinian corals to bleaching (Brown and Suharsono 1990; McClanahan 2000; Nakamura and van Woesik 2001; Baird and Marshall 2002; Riegl 2002; Jones 2008; McCowan et al. 2012). Families of corals that are mostly characterised by branching growth forms (e.g. Acroporidae and Pocilloporidae) are considered to be most susceptible to bleaching and experience highest rates of mortality once bleached (Baird and Marshall 2002; Jones 2008). Families of corals that typically have massive morphologies (e.g. Faviidae, Mussidae, and Poritidae) appear fairly resistant to increasing temperature and are among the last to bleach. They more frequently experience partial mortality rather than whole colony mortality (Brown and Suharsono 1990; McClanahan 2000; Baird and Marshall 2002; Riegl 2002). McCowan et al. (2012) reported that overall patterns of bleaching susceptibility were significantly different among coral growth forms, whereby branching, columnar and tabular corals have greater susceptibility and mortality than massive, submassive, encrusting and free-living corals. Nakamura and van Woesik (2001) reported that flatter and smaller corals have a greater capacity to remove potentially deleterious superoxides and other oxygen radicals, compared to more erect and branching forms. This may explain observations of the present study whereby Acroporids (tabular and branching) tend to be thermally most susceptible and show different bleaching conditions (paling, partial bleaching and complete bleaching) at the onset of a bleaching event. Massive coral $(P$. eydouxi) and solitary coral (Fungia sp.) were thermally most robust among the eight studied corals, with only $15 \%$ of their colonies showing paling in April 2009 prior to the bleaching event.

Interestingly, the results of this study also indicate a differential susceptibility among Acroporids themselves, with $A$. cytherea, A. hyacynthus, and A. muricata showing varying bleaching conditions $(\mathrm{P}, \mathrm{PB}$ and $\mathrm{B})$ at onset of the bleaching event and Acropora sp. showing relatively lower susceptibility/ higher robustness in terms of bleaching conditions, observed only as paling of coral colonies. This differential susceptibility among Acroporids have been explained by the following factors in other studies: variations in morphology (Loya et al. 2001; McCowan et al. 2012); inherent differences in growth rates (Baird and Marshall 2002); thermal tolerances of photoendosymbionts in terms of damage at PSII (Bhagooli and Hidaka 2003; Berkelmans and van Oppen 2006; Bhagooli 2009; Oliver and Palumbi 2011) and/or inhibition of Calvin-Benson cycle (Jones et al. 1998; Bhagooli 2013) ; tissue thickness and/or marked differences in colony size and age (Loya et al. 2001); differential susceptibility and adaptive mechanisms of coral host (Baird et al. 2009); and combined physiology of coral symbiont and coral host forming the holobiont (Sampayo et al. 2008). Bhagooli (2012) also reported that zooxanthellae density of $>0.5, \sim$ $0.2, \sim 0.1$ and $<0.02 \times 10^{6}$ cells $\mathrm{cm}^{-2}$ represented bleaching severity of $0,50,75$ and $>90 \%$, respectively. Horizontal branches of $A$. muricata were more susceptible to bleaching than vertical ones indicating solar bleaching (Bhagooli 2012). Stemming from the above, the differential susceptibility among the Acroporids observed in this study could be explained by variations in morphology and thermal tolerances of endosymbiotic dinoflaggelates.

\section{Post bleaching recovery and PSII functioning among studied corals}

Bleaching state/ recovery conditions were investigated in surveyed coral colonies post-bleaching event in May 2009 until October 2009. During that period, all NB colonies exhibited normal colour and normal chlorophyll $a$ fluorescence ratio $(\mathrm{Fv} / \mathrm{Fm}=0.6)$ Results also indicated a quick recovery in June 2009 of $100 \%$ of $\mathrm{P}$ colonies of $A$. hyacynthus, A. muricata, A. sp., P. damicornis, and $G$. fascicularis to NB condition, to the exception of $A$. cytherea which took slightly longer to recover. Moreover, all PB colonies recorded in May 2009 for A. muricata recovered to NB as from June 2009 onwards indicating a rapid recovery, to the exception of $\mathrm{PB}$ colonies of $A$. cytherea recorded in May 2009 which underwent a slower recovery to NB in August 2009. Similarly, 100\% of B colonies of A. muricata recorded in May 2009 achieved quicker recovery to NB in July 2009, as compared to B colonies for A. cytherea, A. hyacynthus and A. muricata which showed no complete recovery until the month of August 2009.

The above observations suggest that tabular corals $A$. cytherea were more affected by bleaching event and thus took longer to recover. When this observation is tallied by PSII functioning data (Figure 4), it is deduced that recovery of visual condition from $\mathrm{P}$ to NB also involved a recovery of PSII functioning. This observation strongly suggests that recovery of visual appearance/colour of coral may be linked to a recovery of PSII functioning in zooxanthellae. Rodrigues et al. (2008) have demonstrated that $M$. capitata bleached six days earlier than $P$. compressa, and that PSII repair recovered 6.5 months earlier in the latter than in $M$. capitata. The authors suggested that zooxanthellae of $P$. compressa were more resilient to bleaching stress. In this study, it is to be noted that $\mathrm{P}$ colonies of $P$. damicornis and G. fascicularis, although pale in appearance, showed no remarkable change or improvement in PSII functioning, suggesting that paling may have involved loss of pigments rather than damage to PSII functioning of Chl $a$ of zooxanthellae symbionts in these two species of scleractinian corals. This observation may be explained by the fact that flatter and smaller corals have a greater capacity to remove potentially deleterious superoxides and other oxygen radicals, compared to more erect and branching forms (Nakamura and van Woesik 2001). Bhagooli and Yakovleva (2004) also demonstrated 
bleaching susceptibility and mortality in massive coral Platygyra ryukyuensis (no mortality) and Seriatopora caliendrum (100\% mortality) after exposure to thermal stress.

When comparing bleaching conditions/ visual status/ coloration of PB and B corals with their PSII functioning data, it is noted that that recovery from $\mathrm{B}$ to $\mathrm{PB}, \mathrm{PB}$ to $\mathrm{P}$ and $\mathrm{P}$ to NB conditions normally involved an improvement of PSII functioning of photosynthetic apparatus of coral symbionts. In PB and B samples, A. muricata normally exhibited higher Fv/Fm values as compared to other two Acroporids, A. cytherea and A. hyacynthus, showing a faster recovery of functioning of Chl $a$ in its zooxanthellar symbionts in the months of June and July 2009. All P, PB and $\mathrm{B}$ samples in this study gained in coloration by October 2009, at same time showing an improvement in PSII functioning.

The results indicated that recovery of zooxanthellae $\mathrm{Chl}$ $a$ fluorescence, i.e. PSII functioning (to $\mathrm{Fv} / \mathrm{Fm}=0.6$ ) varied among the studied corals within days and/or months, with some recovering faster (A. muricata and A. sp.) and others recovering much slower (A. cytherea and $A$. hyacynthus). Although showing a loss of coloration (visual paling) during the bleaching event and subsequent gain of coloration (visual non-bleaching) post-bleaching event, $P$. damicornis and $G$. fascicularis showed no remarkable changes in fluorescence quantum yield during and postbleaching event. Higher bleaching susceptibility in $A$. cytherea and A. hyacynthus, and their slower recovery in terms of PSII functioning was also observed. Jones and Yellowlees (1997) have reported the manner by which a bleached colony of a staghorn coral, Acropora formosa (Dana 1846), now Acropora muricata, recovered its algal symbionts after a major bleaching event and the processes involved in its algal regulation and control. The authors suggested that algal cell size in their study appeared invariant of seasonal change, zooxanthellae density, chl $a$ concentration and division frequency. If algal size can be determined by host or external light conditions or nutrient supply, then it may ultimately determine the whole nature of the association.

Differential post-bleaching recovery among studied species may suggest a chronic photoinhibition, also indicating that photodamage may have affected the structures and functions of PSII in these species ((Jones and Hoegh-Guldberg 2001). Mechanisms of recovery can be explained by the following: elevated $\mathrm{Chl} a$ per zooxanthellae (Rodrigues et al. 2008); an increase in mitotic index and therefore number of zooxanthellae cells (Bhagooli 2012a); zooxanthellar density in terms of zooxanthellae reproduction and zooxanthellae release rates from bleached hosts (Jones and Yellowlees 1997); space availability and size of algal symbionts (Jones and Yellowlees 1997); repair of donor side of PSII (Rodrigues et al. 2008); reduced metabolic rates (decreased net photosynthesis and coral plus zooxanthellae respiration) (Rodrigues and Grottoli 2007); zooxanthellae clade types (Baker et al. 2004; Mc Clanahan et al. 2005); morphological variability on surface skeleton of host as a means for photoprotection (Bhagooli 2012b); and host's strategies during recovery, for example, stored energy reserves and photosynthetically acquired carbon and/or heterophically acquired carbon by host feeding when photosynthesis is not available by the symbionts (Rodrigues et al. 2008); nutrient limitations for zooxanthellae growth (Jones and Yellowlees 1997). Also, the activity at one or more other levels within the chloroplast (i.e. electron transport, photosystem I, ATP synthase, or carbon fixation) may differ between zooxanthellae types and coral species, and account for visible differences in bleaching and recovery (Smith et al. 2006; Tchernov et al. 2004). Resilience of zooxanthellae symbiont and/or resilience of coral host are also important in determining rate of recovery (Rodrigues et al. 2008). Anthony et al. (2009) reported that survival following bleaching was also strongly influenced by remaining lipid reserves, rates of heterotrophy, and rates of photopigment (or symbiont) recovery. However, these factors were not measured within this study, and provide an opportunity for further investigation to look into effect of zooxanthellae size, density, clades and gene expression in both coral animal host and Symbiodinium (Louis et al. 2017). The observations made in this study might also be compared to a non-bleaching year.

In conclusion, the results of the study highlight a differential recovery among eight studied species of reefbuilding corals, in terms of recovery of colour (visual condition) and recovery of the PSII functioning of zooxanthellae endosymbionts, post-May 2009 bleaching event. The order of recovery was as follows: Massive-like/ solitary corals > Branching and semi-bulbous corals > tabular corals. Rate of recovery was fastest in $P$. damicornis and G. fascicularis, followed by Acropora sp., and lastly by $A$. cytherea and A. hyacynthus. Normally, a recovery in bleaching condition, i.e. gain in coloration from $\mathrm{B}$ to $\mathrm{PB}, \mathrm{PB}$ to $\mathrm{P}$ and $\mathrm{P}$ to $\mathrm{NB}$, also indicated a recovery of PSII functioning $\mathrm{n}$ coral to the exception of $P$. damicornis and G. fascicularis.

\section{ACKNOWLEDGEMENTS}

The authors are thankful to the Faculty of Science, University of Mauritius for logistical support. SMM is grateful to the then Ministry of Fisheries (now Ministry of Ocean Economy, Marine Resources, Fisheries, Shipping and Outer Island), Republic of Mauritius, for granting permit for sample collection, and to the Mauritius Research Council (MRC) for postgraduate award for part of this study.

\section{REFERENCES}

Anthony KRN, Hoogenboom MO, Maynard JA, Grottoli AG, Middlebrook R. 2009. Energetics approach to predicting mortality risk from environmental stress: a case study of coral bleaching. Funct Ecol 23: 539-550.

Baird AH, Bhagooli R, Nonaka M, Yakovleva I, Yamamoto HH, Hidaka M, Yamasaki H. 2010. Environmental controls on the establishment and development of algal symbiosis in corals. Proceedings of the 11th 
International Coral Reef Symposium, Ft. Lauderdale, Florida, 7-11 July 2008, 108-112.

Baird AH, Marshall PA. 2002. Mortality, growth and reproduction in scleractinian coral following bleaching on the Great Barrier Reef. Mar Ecol Prog Ser 237: 133-141.

Baird AH, Bhagooli R, Ralph PJ, Takehashi S. 2009. Coral Bleaching: the role of the host. Trends Ecol Evol 24: 16-20.

Baker AC, Glynn PW, Riegl B. 2008. Climate change and coral reef bleaching: An ecological assessment of long-term impacts, recovery trends and future outlook. Estuar Coastal Shelf Sci 80: 435-471.

Baker AC, Starger CJ, Mcclanahan TR, Glynn PW. 2004. Coral reefs: corals' adaptive response to climate change. Nature 430 (7001): 741.

Berkelmans R, Van Oppen MJH. 2006. The role of zooxanthellae in the thermal tolerance of corals: a 'nugget of hope' for coral reefs in an era of climate change. Proc R Soc London 273: 2305-2312.

Bhagooli R. 2009. Symbiont-dependent thermal bleaching susceptiblity in two reef-building corals, Stylophora pistillata and Platygyra ryukyuensis. Univ Mauritius Res J 15 (1): 607-626.

Bhagooli R. 2012a. The application of a bleaching index as a potentia tool for monitoring coral health. Univ Mauritius Res J 18A: 88-104.

Bhagooli R. 2012b. Light-induced production of tuberculae on exposed coral surfaces of the coral Montipora capitata. Univ Mauritius Res J 18A: $145-165$

Bhagooli R. 2013. Inhibition of Calvin-Benson cycle suppresses the repair of photosystem II in Symbiodinium: implications for coral bleaching. Hydrobiologia 714 (1): 183-190.

Bhagooli R, Baird AH, Ralph PJ. 2008. Does the coral host protect its algal symbionts from heat and light stresses. Proceedings of the 11th International Coral Reef Symposium, Ft. Lauderdale, Florida, 7-11 July 2008, 5, 113-117.

Bhagooli R, Hidaka M. 2003. Comparison of stress susceptibility of in hospite and isolated zooxanthellae among five coral species. J Exp Mar Biol Ecol 291 (2): 181-197.

Bhagooli R, Hidaka M. 2006. Thermal inhibition and recovery of the maximum quantum yield of photosystem II and the maximum electron transport rate in zooxanthellae of a reef-building coral. J Jpn Coral Reef Soc 8 (1): 1-11.

Bhagooli R, Yakovleva I. 2004. Differential bleaching susceptibility and mortality patterns among four corals in response to thermal stress. Symbiosis 37 (1-3): 121-136.

Brown B, Dunne R, Goodson M, Douglas A. 2002. Experience shapes the susceptibility of a reef coral to bleaching. Coral Reefs 21 (2): 119126.

Brown BE, Suharsono. 1990. Damage and recovery of coral reefs affected by El Nino related sea water warming in the Thousand Islands, Indonesia, Coral Reefs 8: 163-170.

Brown BE, Dunne RP, Warner E, Ambarsari I, Fitt WK, Gibb W, Cummings DG. 2000. Damage and recovery of Photosystem II during a manipulative field experiment on solar bleaching in the coral Goniastrea aspera. Mar Ecol Prog Ser 195: 117-124.

Fitt WK, Brown BE, Warner ME, Dunne RP. 2001. Coral bleaching. Interpretation of thermal tolerance limits and thermal thresholds in tropical corals. Coral Reefs 20: 51-65.

Fitt WK, Warner ME. 1995. Bleaching patterns of four species of Caribbean reef corals. Biol Bull (Woods Hole) 189: 298-307.

Genty B, Briantais JM, Baker NR. 1989. The relationship between the quantum yield of photosynthetic electron transport and quenching of chlorophyll fluorescence. Biochimica Biophysica Acta 990: 87-92

Grottoli AG, Rodrigues LJ, Palardy J E. 2006. Heterotrophic plasticity and resilience in bleached corals Nature 440: 1186-1189

Iglesias-Prieto R. 1997. Temperature-dependent inactivation of photosystem II in symbiotic dinoflagellates. Proceedings of the Eighth International Coral Reef Symposium (Panama) 2, 1313-1318.

Iglesias-Prieto R, Matta JL, Robins WA, Trench R K. 1992 Photosynthetic response to elevated temperature in the symbiotic dinoflagellate Symbiodinium microadriaticum in culture. Proc Nat Acad Sci USA 89 10302-10305.

Jones RJ. 2008. Coral bleaching, bleaching-induced mortality, and the adaptive significance of the bleaching response. Mar Biol 154 65-80

Jones RJ, Hoegh-Guldberg O. 2001. Diurnal changes in the photochemical efficiency of the symbiotic dinoflagellates (Dinophyceae) of corals: photoprotection, photoinactivation and the relationship to coral bleaching. Plant Cell Environ 24 89-99.

Jones RJ, Yellowlees D. 1997. Regulation and control of intracellular algae (= zooxanthellae) in hard corals. Phil Trans R Soc London 352 $457-468$
Jones RJ, Hoegh-Guldberg O, Larkum AWD, Schreider U. 1998. Temperature-induced bleaching of corals begins with impairment of the $\mathrm{CO}_{2}$ fixation mechanism in zooxanthellae. Plant Cell Environ 21: 1219-1230.

LaJeunesse TC, Smith RT, Finney J, Oxenford H. 2009. Outbreak and persistence of opportunistic symbiotic dinoflagellates during the 2005 Caribbean mass coral 'bleaching' event. Proc R Soc B Bil Sci 276: 4139-4148.

Lesser MP. 1996. Elevated temperature and ultraviolet radiation cause oxidative stress and inhibit photosynthesis in symbiotic dinoflagellates. Limnol Oceanogr 41: 271-283.

Louis Y D, Kaullysing D, Gopeechund A, Mattan-Moorgawa S, Bahorun T, Dyall S D, Bhagooli R. 2016. In hospite Symbiodinium photophysiology and antioxidant responses in Acropora muricata on a coast-reef scale: implications for variable bleaching patterns. Symbiosis 68 (1-3): 61-72.

Louis YD, Bhagooli R, Kenkel CD, Baker AC, Dyall SD. 2017. Gene expression biomarkers of heat stress in scleractinian corals: Promises and limitations. Comp Biochem Physiol C: Toxicol Pharmacol 191: 63-77.

Loya Y, Sakai K, Yamazato K, Nakano J, Sambi H., Van Woesik R. 2001. Cora bleaching: the winners and the losers. Ecol Lett 4: 122-131.

Mattan-Moorgawa S, Bhagooli R, Rughooputh SDDV. 2012. Thermal stress physiology and mortality responses in scleractinian corals of Mauritius. Proceedings of the 12th International Coral Reef Symposium, Cairns, Australia, 9-13 July 2012. ICRS 2012, 9A,

Mc Clanahan TR. 2000. Recovery of a coral reef keystone predator, Balistapus undulates, in East African marine parks. Biol Conserv 94: 191-198.

Mc Clanahan TR, Maina J, Moothien-Pillay R, Baker AC. 2005. Effects of geography, taxa, water flow and temperature variation on coral bleaching intensity in Mauritius. Mar Ecol Prog Ser 298: 131-142.

Mccowan DM, Morgan S, Pratchett MS, Baird AH. 2012. Bleaching susceptibility and mortality among corals with differing growth forms. Proceedings of the 12th International Coral Reef Symposium, Cairns, Australia, 9-13 July 2012,9A.

Muscatine L, McCloskey L R, Marian R E. 1981. Estimating the daily contributing of carbon from zooxanthellae to coral animal respiration. Limnol Oceanogr 36 (4): 601-610.

Nakamura T, Van Woesik R. 2001. Water flow rates and passive diffusion partially explain differential survival of corals during the 1998 bleaching event. Mar Ecol Prog Ser 212: 301-304.

Oliver TA, Palumbi SR. 2011. Many corals host thermally resistant symbionts in high-temperature habitat. Coral Reefs 30: 241-250.

Rodrigues LJ, Grottoli AG. 2007. Energy reserves and metabolism as indicators of coral recovery from bleaching. Limnol Oceanogr 52: 1874-1882.

Rodrigues LJ, Grottoli AG, Lesser MP. 2008. Long-term changes in the chlorophyll fluorescence of bleached and recovering corals from Hawaii. J Exp Biol 211: 2502-2509.

Sampayo EM, Ridgeway T, Bongaerts P, Hoegh-Guldberg O. 2008. Bleaching susceptibility and mortality of corals are determined by fine-scale differences in symbiont type. Proc Natl Acad Sci USA 105 (30): 10444-10449.

Smith D J, Suggett DJ, Baker NJ. 2005. Is photoinhibition of zooxanthellae photosynthesis the primary cause of thermal bleaching in corals? Global Change Biol 11: 1-11.

Tchernov D, Gorbunov MY, Vargas CD, Yadav SN, Milligan AJ, Haggblom M, Falkowski PG. 2004. Membrane lipids of symbiotic algae are diagnostic of sensitivity to thermal bleaching in corals. Proc Natl Acad Sci USA 101: 13531-13535.

Thornhill DJ, LaJeunesse TC, Kemp DW, Fitt WK, Schmidt GW. 2006. Multi-year, seasonal genotypic surveys of coral-algal symbioses reveal prevalent stability or post-bleaching reversion. Mar Biol 148 711-722.

Trapido-Rosenthal H, Zielke S, Owen R, Buxton L, Boeing B, Bhagooli R, Archer J. 2005. Increased zooxanthellae nitric oxide synthase activity is associated with coral bleaching. Biol Bull 208: 3-6.

Van Woesik R, Sakai K, Ganase A, Loya Y. 2011. Revisiting the winners and losers a decade after coral bleaching. Mar Ecol Prog Ser 434: 6776.

Visram S, Douglas AE. 2007. Resilience and acclimation to bleaching stressors in the scleractinian coral Porites cylindrica. J Exp Mar Biol Ecol 349 (1): 35-44. 
Warner M E, Fitt W K, Schmidt G W. 1999. Damage to photosystem II in symbiotic dinoflagellates: A determinant of coral bleaching. Proc Natl Acad Sci USA 96: 8007-8012.
Warner ME, Fitt WK, Schmidt WG. 1996. The effects of elevated temperature on the photosynthetic efficiency of zooxanthellae in hospite from four different species of reef coral: a novel approach. Plant Cell Environ 19: 291-299. 